\title{
Effectiveness of a Peptide-rich Fraction from Xenorhabdus budapestensis Culture against Fire Blight Disease on Apple Blossoms
}

\author{
Dávid VOZIK ${ }^{1 *}$, Katalin BÉLAFI-BAKÓ ${ }^{1}$, Mária HEVESI ${ }^{2}$, \\ Erzsébet BÖSZÖRMÉNYI ${ }^{3}$, András FODOR ${ }^{4}$
}

\author{
${ }^{1}$ University of Pannonia, Research Institute on Bioengineering, Membrane Technology and Energetics, Egyetem u. 10, H-8200, Vexpprém, \\ Hungary;vozikd@gmail.com ("correspondingauthor);bako@almos.uni-pannom.bu \\ 2Corvinus University of Budapest, DepartmentofPomology, Ménesiút 29-43, H-1118, Budapest, Hungary; maria hevesi@uni-cominus.hu \\ ${ }_{3}^{3}$ Semmehweis University, DepartmentofEpidemiology,Vasu.17,H-1088, Budapest, Hungary; boszormenyie@se-etk.bu \\ ${ }^{4}$ UniversityofWisconsin-Madisom,Department of Bacteriology, 1550Linden Drive, Madison, Room 4526,WI53507, USA; fodorandras@yahoo.com
}

\begin{abstract}
Erwinia amylovora is one of the most frequently occurred plant pathogenic bacterium. It causes necrosis and blight symptoms on host plants and it lead to considerable yield losses throughout the world on apple trees. There is no effective chemical treatment is currently available against fire blight. The purpose of the present study was to search a new, alternative control method. The evaluation of the plant protection potential of an enriched fraction of Xenorhabdus budapestensis cell-free conditioned media was investigated. Purified samples were tested in vitro and in planta against the phytopathogenic bacterium. A reproducible method for isolation of a peptide-rich fraction from Xenorhabdus cell-free conditioned media was established. The process resulted in $400 \mathrm{mg}$ of dry sample prepared from three litres of Xenorhabdus cell culture. Significant correlation was found between the concentration of the purified preparation and the induced inactivation zones against Erwinia amylovora Eal in agar diffusion test method. The minimum inhibitory concentration and minimum bactericidal concentration of the purified fraction against Eal strain were $8 \mu \mathrm{g} / \mathrm{mL}$ and $16 \mu \mathrm{g} / \mathrm{mL}$, respectively. In planta experiments were tested on an apple cultivar ('Watson Jonathan') susceptible to fire blight. The effective range of concentration was $62-200 \mu \mathrm{g} / \mathrm{mL}$, while treatment with $300 \mu \mathrm{g} / \mathrm{mL}$ and larger amounts caused necrotic symptoms on the petals of flowers. Current study pointed to the effectiveness of the compounds produced by $X$. budapestensis against fire blight. The development of a commercially applicable formulation of these compounds would allow growers to effectively control fire blight in apple and pear orchards.
\end{abstract}

Keywords: agrobiologicals, antagonists, antimicrobial compounds, entomopathogenic bacteria, infection, prevention

\section{Introduction}

Bacterial infections are among the major cause of mortality and morbidity, thus can severely limit the commercial productivity of fruit trees all over the world (Dzotam et al., 2015). One of the most dangerous diseases of plants in the Rosaceae family is the fire blight, caused by Erwinia amylovora that affects many crops in agriculture and horticulture especially apple and pear trees (Malnoy et al., 2012). During the last decades, E. amylovora spread in the Mediterranean Basin and Western Europe from North-America (Bonn and van der Zwet, 2000). Appearance of the plant pathogenic bacterium in Hungary has been reported for the first time in 1995 (Hevesi, 1996). Nowadays there are almost no countries in Europe devoid of fire blight (Thomson, 2000). Previously, protection against fire blight disease was based on the use of the antibiotic streptomycin sulfate, which is restricted by the laws in numerous countries in Europe, because of its use in human public healthcare. Moreover, there are various natural isolates of streptomycin-resistant $E$. amylovora strains, mostly from the area of North-America (McManus and Jones, 1994; Norelli et al., 1994; Sobiczewski et al., 1991). Therefore, curative control of $E$. amylovora on apples and pears are lacking at present. Any future strategy, preventive or curative chemotherapy should be based on the application of antibacterial compounds which do not show cross resistance with any commercially used antibiotics. Recent studies demonstrate differences in sensitivity of apple cultivars to the infection caused by E. amylovora (Tóth et al., 2013; Viljevac et al., 2009). Therefore, resistance breeding programmes can offer a long-term solution, but meanwhile, effective and safe ingredients of control must be improved to prevent damage of these fruit crops. 
Increasing antimicrobial resistance has created a critical need to search new antibiotics with novel mechanisms of action and to develop anti-infective products against the pathogens. The natural compounds produced by entomopathogenic bacteria (EPB) species seem to be one of the promising alternatives.

Entomopathogenic bacteria like Photorhabdus and Xenorhabdus species, belonging to the bacterial family Enterobacteriaceae, are symbiotically associated with entomopathogenic nematodes (EPN) as Heterorhabditis and Steinernema species (Boemare et al., 1993; Thomas and Poinar, 1979). These nematode-bacteria complexes can be used as biological control agents against insect pests in agriculture (Smart, 1995). The bacterial symbionts produce several important secondary non-ribosomal products (NRP) with biological activity. They include smaller organic compounds, which in cooperation with hydrolytic exo-enzymes, process the insect's cadaver into utilizable nutrients for nematodes and thereby protect it from microbial competitors. Dutky et al. (1964) proposed that the bacteria which live as symbionts of the EPN are able to produce compounds with antibiotic effect, as well. Some of these antimicrobial compounds - mainly secondary metabolites act either alone or synergistically, significantly contribute to the broad-scale protection of colonized cadaver under the polyxenic soil conditions, providing nearly monoxenic conditions within the colonized insect cadavers (Akhurst, 1982). Recent interest has turned toward biologically active NRP peptides and their hybrids with different organic residues. Lengyel et al. (2005) had previously described $X$. budapestensis, and deposited the strain in DSMZ, Germany as DSM 16342. Fuchs et al. $(2012,2014)$ working with $X$. budapestensis and found that some of these substances produced by these bacteria, especially the fabclavines show strong antibacterial activity against numerous Gram-positive and Gram-negative pathogenic bacteria as well as some fungi of agricultural importance. Fodor et al. (2012) also worked with this $\mathrm{EPB}$ species, and investigated and described the target-spectra of antimicrobial compounds produced by it, against a wide range of plant pathogenic bacteria and fungi.

The natural agents of EPB species have shown a wide range of bioactivities of medical and agricultural interest, such as antibiotic, antimycotic and insecticidal effects (McInerney et al., 1991; Webster $e t$ al., 2002). Several secondary metabolite molecules produced by $X$. budapestensis are antimicrobial peptides (AMP), like bicornutin-A (Böszörményi et al., 2009), GP-19 and EP-20 (Xiao et al., 2012). A recently discovered peptide-polyketidepolyamine hybrid family, called fabclavines with a broadspectrum of bioactivity, produced by $X$. budapestensis DSM 16342 (Fuchs et al., 2014), might be of an excellent potential. These substances have additional favorable properties, such as low molecular weight and thermal stability. In addition, targeted microorganisms are not able to induce resistance easy against $\operatorname{AMPs}$ (Hastings et al., 2004).

The main objectives of the present study were to carry out and evaluate biological assays for investigate the potential of $X$. budapestensis DSM 16342 (EMA) for plant protection. The bioactive compounds were purified and tested also in a cleaner form. After accomplishing several in vitro tests we focused on the control of E. amylovora in planta. We applied a purified peptiderich fraction $(\mathrm{PF})$ prepared from $X$. budapestensis culture and examined its effectiveness in the protection of apple blossoms against $E$. amylovora, using a modified version of the method reported by Pusey (1999). The effect of Xenorhabdus products with different purity and composition on apple blossoms must also explain.

\section{Materials and Methods}

Testorganisms and media

Entomopathogenic bacterium

Antagonistic bacterium strain used in this study was previous isolate from Xenorhabdus budapestensis DSM-16342 ${ }^{\mathrm{T}}$ (EMA), separated before deposition and has been kept in selective conditions since then. EMA was routinely cultured in Luria-Bertani Broth and modified Luria Agar (casein peptone $10 \mathrm{~g} / \mathrm{L}$, yeast extract $5 \mathrm{~g} / \mathrm{L}$, sodium chloride $10 \mathrm{~g} / \mathrm{L}$, agar $17 \mathrm{~g} / \mathrm{L}$ ) (LB and LA, respectively) (Ausubel et al., 1999) at $25^{\circ} \mathrm{C}$. The indicator plates (LBTA) were supplemented with bromothymol blue (BTB) and 2, 3, 5triphenyltetrazolium chloride (TTC), and were used to distinguish AMP producing (phase I) and non-producing (phase II) variants (Leclerc and Boemare, 1991). Fresh single colonies derived from frozen bacterial stocks were used for each experiment. Microbiological media were obtained from BiolabZrt., Hungary.

\section{Plantpathogenic bacterium}

Erwinia amylovora Eal strain was collected by M. Hevesi from an apple tree at Nyárlörinc, Hungary (Hevesi, 1996). Eal has been deposited in the National Collection of Agricultural and Industrial Microorganisms (NCAIM), Hungary under the number B.01728. The test bacterium was cultured in LB liquid and on LA solid media.

\section{Testplants}

For in planta bioassay, blossoms of 'Watson Jonathan' apple were chosen. This variety had been previously reported to be susceptible to fire blight (van der Zwet and Beer, 1995). Plant materials were obtained from the apple collections at the Soroksár Research Station of the Department of Pomology, Corvinus University of Budapest.

\section{Preparation of Xenorbabdus cell-free media (CFCM)}

$X$. budapestensis was maintained on LA medium and subcultured freshly. The AMP producing phase I has instability under normal culture conditions, therefore, glycerinated frozen stocks of the bacteria were used as a starting material for culture. In order to ensure the presence of phase I, stocks were incubated on LBTA plates at $25^{\circ} \mathrm{C}$. Single black - dark blue colonies were added separately into test tubes containing $3 \mathrm{~mL}$ of LB liquid medium. At the end of the $\log$ phase the cell culture was inoculated into 50 $\mathrm{mL}$ of LB in $500 \mathrm{~mL}$ flasks. $50 \mathrm{~mL}$ aliquots of culture grew overnight at $25^{\circ} \mathrm{C}$, then were inoculated to $250 \mathrm{~mL}$ of LB in 1000 $\mathrm{mL}$ flasks and incubated on a gyrorotatory shaker (200 rpm) at 25 ${ }^{\circ} \mathrm{C}$ until stationary phase. The cells were removed by centrifugation $(15000 \times \mathrm{g})$ for $20 \mathrm{~min}$ at $4^{\circ} \mathrm{C}$. A supernatant was filtered through Millipore Express Plus filter (pore-sizes $0.22 \mu \mathrm{m}$ ) (Merck Millipore), to obtain a cell-free filtrate. The filtrate was stored at $4^{\circ} \mathrm{C}$ until its utilization. 


\section{Purifcation of a peptide-rich fraction (PF) from X. budapestensis CFCM}

Three litres of X. budapestensis cell-free media were processed for further purification. CFCM was mixed with a polymeric adsorbent Amberlite XAD-1180 (Alfa Aesar GmbH \& Co KG, Germany) in a concentration $20 \mathrm{~g} / \mathrm{L}$. The adsorbent was previously activated in distilled water in an autoclave at $121{ }^{\circ} \mathrm{C}$ for $30 \mathrm{~min}$. The resin containing CFCM was incubated at $25^{\circ} \mathrm{C}$ in a gyrorotatory shaker at $150 \mathrm{rpm}$ for $48 \mathrm{~h}$. The resin slur was removed by filtration on a glass filter and washed thoroughly with $1000 \mathrm{~mL}$ of sterile distilled water. Amberlite adsorbent was placed on the top of the Millipore Express Plus filter of $0.45 \mu \mathrm{m}$ pore-sizes (Merck Millipore), washed with $500 \mathrm{~mL}$ of $25 \%$ methanol, and $3 \times 300 \mathrm{~mL}$ of $50 \%$ methanol in order to remove all coloured and inactive materials. Subsequently, $3 \times 300 \mathrm{~mL}$ of $80 \%$ methanol was used to elute some additional compounds, mainly triptamine. Finally, the active compounds were eluted with $300 \mathrm{~mL}$ of $100 \%$ methanol (Molar Chemicals kft, Budapest, Hungary) containing $3 \mathrm{~mL}$ of $2 \mathrm{~N}$ HCL. This acidic solution was neutralized $(\mathrm{pH} \sim 6)$ with $2 \mathrm{~N} \mathrm{NH} 4 \mathrm{OH}$, and evaporated by Heidolph VV 2000 rotary vacuum evaporation system. The method resulted in $400 \mathrm{mg}$ of dry, biologically active preparation.

\section{In vitro bioassays}

Antibacterial activity on solid media

Overlay bioassay was carried out as previously described (Böszörményi et al., 2009; Furgani et al., 2008), and was conducted to determine antibiotic activity, reifying antagonistic effect of living Xenorbabdus cells. Overlay test was done in quadruplicate sets of plates.

Antimicrobial activity of CFCM from $X$. budapestensis was followed by agar diffusion hole test method (Fodor et al., 2012). Briefly, $300 \mu \mathrm{L}$ of an overnight cell culture of the test bacterium (Ea1) was mixed with $5 \mathrm{~mL}$ soft agar $(0.6 \%$ agar), which was previously been warmed in a water bath thermostat to approximately $45^{\circ} \mathrm{C}$ and then poured on the surface of LA plates. Then an $8 \mathrm{~mm}$ diameter hole was made in the centre of each plate with a sterile cork borer, and $200 \mu \mathrm{L}$ volume of the antimicrobial solution was added. The plates were incubated at $25^{\circ} \mathrm{C}$ for $48 \mathrm{~h}$, and inactivation zones were evaluated by measuring of their diameters. Tests were performed in triplicate. Culture filtrates, diluted with sterile LB liquid media, were tested in four different concentrations $(40,60,80,100$ $\%(\mathrm{~V} / \mathrm{V}))$. Effectiveness of PF from $X$. budapestensis was also tested against $E$. amylovora Eal at eight different concentrations $(40,62,100,150,200,300,500,1000$ $\mu \mathrm{g} / \mathrm{mL})$.

\section{Determination of bacterial toxicity in liquidmedia}

Cell-free media of $X$. budapestensis was serially diluted in microtiter plates with LB $(100,80,60,50,40,30,20,10$ and $0 \%$ (V/V), respectively). Each well contained $1950 \mu \mathrm{L}$ CFCM and was supplemented with $50 \mu \mathrm{L}$ cell suspension from an overnight culture of Eal. The cultures were shaken $(120 \mathrm{rpm})$ at $25^{\circ} \mathrm{C}$ for 24 h. The cell densities were determined spectrophotometrically by Hach-Lange DR 3900 spectrophotometer, at $620 \mathrm{~nm}$. Results were given by plotting OD values versus dilution of CFCM. Moreover, $50 \mu \mathrm{L}$ samples were plated onto LA plates. MID (maximum inhibitory dilution) is defined as the highest dilution of CFCM where test bacteria were unable to grow. Three replicates of plates were used for the experiment. The highest dilution means the lowest concentration of an active substance tested. Determination of the minimum inhibitory concentration (MIC) and minimum bactericidal concentration (MBC) of the PF against $E$. amylovora $\mathrm{Eal}$

To evaluate antimicrobial activity of the prepared peptide-rich fraction, purified from $X$. budapestensis culture, two parameters were determined. The MIC was performed by using the macro dilution method recommended by the Clinical and Laboratory Standards Institute, USA (CLSI, 2012). The minimum bactericidal concentration (MBC) was determined as the lowest concentration of an antibacterial agent $(\mathrm{PF})$ required to kill $E$. amylovora Eal. It was determined from broth dilution minimum inhibitory concentration (MIC) tests by subculturing to agar plates that do not contain the test agent. The PF fraction was dissolved in methanol to give a concentration of $10 \mathrm{mg} / \mathrm{mL}$ and then diluted to concentrations $1000-1.0 \mu \mathrm{g} / \mathrm{mL}$ with sterile distilled water. Broth medium without PF was used as growth control. Cell suspension of Eal equivalent to a $0.5 \mathrm{McF}$ arland standard was made as inoculum for working solutions resulted in a final inoculum of $5 \times 10^{5} \mathrm{CFU} / \mathrm{mL}$. Tubes were incubated at 28 ${ }^{\circ} \mathrm{C}$ for $24 \mathrm{~h}$. The MIC value is defined as the lowest concentration of the examined material that prevented visible bacterial growth. Three replicates for each concentration of the test sample were tested.

The method of Smith-Palmer et al. (1998) was adopted to determine MBC value. $100 \mu \mathrm{L}$ from the MIC tubes, which showed no bacterial growth were serially diluted and plated on LA plates. The plates were incubated at $28^{\circ} \mathrm{C}$ for $48 \mathrm{~h}$. MBC was defined as the lowest concentration of antimicrobials where bacteria were not be able to grow on LA inoculated with $50 \mu \mathrm{L}$ of solution. Three replicates of plates were used for each concentration of the test sample.

\section{Inplantabioassay \\ Effectiveness of PF on apple blossoms}

Efficiency of PF obtained from $X$. budapestensis culture to control fire blight disease was determined according to the method reported by Tóth et al. (2013). 300 pieces of 'Watson Jonathan' flowers (at Soroksár Research Station, Hungary) were collected at "balloon state", and were placed separately in tubes, filled with $1 \%$ sucrose solution. Flowers were incubated at $23^{\circ} \mathrm{C}$ and $84 \%$ relative humidity in transparent plastic boxes for $12 \mathrm{~h}$. Afterwards, opened flowers were treated with aqueous solutions of PF by employing a hand-sprayer. About three hours later, the flowers were inoculated with $10 \mu \mathrm{L}$ of Eal suspension with a cell density of $5 \times 10^{8}$ $\mathrm{CFU} / \mathrm{mL}$ by applying an automatic pipette. Ten concentrations of PF from 500 to $4 \mu \mathrm{g} / \mathrm{mL}$ were tested in ten different plastic boxes. Each experimental box contained 20 previously treated flowers and 5 control flowers treated with distilled water. All of them were artificially infected with Eal test bacterium. The control box contained 50 pieces of not infected, water-treated flowers.

After 5 days the infected flowers were cut lengthwise and evaluated based on the severity of disease symptoms using a 
550

modified version of the rating scale recommended by Pusey (1999), where means of the values were represented as follows: 0 no necrosis, 1 - detectable necrosis (just on the stamens), 2 necrosis on up to half of the ovary, 3 - half to all of the ovary was affected by necrosis or spreading across the ovary to the peduncle. The blight rating concerning the flowers previously treated by the same concentration were indicated with $\mathrm{B}_{\mathrm{f}}$ and was calculated applying the formula reported by Bertrand and Gottwald (1978): $\sum \mathrm{f}_{\mathrm{i}} \times \mathrm{n}_{\mathrm{i}} / \mathrm{n}$, where $f_{i}$ indicated the individual infection rate of the flowers, $n_{i}$ is the frequency of either one infection rate and $n$ is the number of flowers examined in the same way treatment.

To verify the effectiveness of the treatments the numbers of viable Eal cell counts on the flowers were determined. Flowers belonging to the same treatment group were ground with mortar and pestle using $100 \mu \mathrm{L}$ added sterile distilled water per flower. Aliquots were serially diluted with sterile distilled water and performed in duplicates. $50 \mu \mathrm{L}$ from the diluted samples were plated onto LA media with two parallel replicates, and plates were incubated at $25^{\circ} \mathrm{C}$ for $48 \mathrm{~h}$. The number of viable E. amylovora cells was determined. The $\mathrm{CFU} /$ flower value was calculated from the average of colony numbers on replicate plates.

\section{Statisticalanalyses}

The results subjected to ANOVA and Scheffé test (post hoc) were used to establish mean differences between doses of CFCM (agar diffusion test) at a significance level of $\mathrm{p}<0.05$.

PF obtained from $X$. budapestensis in eight different concentrations was also tested by agar diffusion method against Eal test bacterium. Null hypothesis was that there is a relationship between the doses of $\mathrm{PF}$ and the induced inactivation zones, therefore correlation of the data was investigated.

The disease symptoms (degree of the necrotic areas) of the apple blossom samplings infected with $E$. amylovora Eal and treated with PF from $X$. budapestensis were analysed as a fully randomized experiment and non-parametric Kruskal-Wallis test was used to discriminate between treatments. Correlation between the doses of PF-treatment and the number of viable Eal cells based on the isolation from apple flower samples was also examined.

All statistical analyses were performed using STATISTICA 8 (StatSoft Inc, Tulsa, OK, USA).

\section{Results}

\section{Invitro bioassays}

The results of overlay bioassay show, that the tested plant pathogenic bacterium (Eal) proved sensitive to EMA. Mean ( \pm standard error) inactivation zone averaged $44.75 \pm 0.96 \mathrm{~mm}$.

Antibacterial activity of CFCM of EMA on E. amylovora Eal was determined in four concentrations by agar diffusion tests. Data are summarized in Fig. 1. The four columns from the left to right represent the respective doses of $40,60,80$ and $100 \%$ (V/V) of EMA CFCM. The effect was statistically not dose dependent in all of the cases on the grounds of Scheffé test. However, there were perceptible differences between the averages of induced inhibition zones in accordance with concentration of CFCM.

PF from $X$. budapestensis was also tested for inactivation zones against $E$. amylovora Eal. Data and the fitted line are summarized in Fig. 2. The abscissa represents the dose $(\mu \mathrm{g} / \mathrm{mL})$ of the PF, while the ordinate demonstrates the diameter of the induced inactivation zone in $\mathrm{mm}$. Significant correlation was

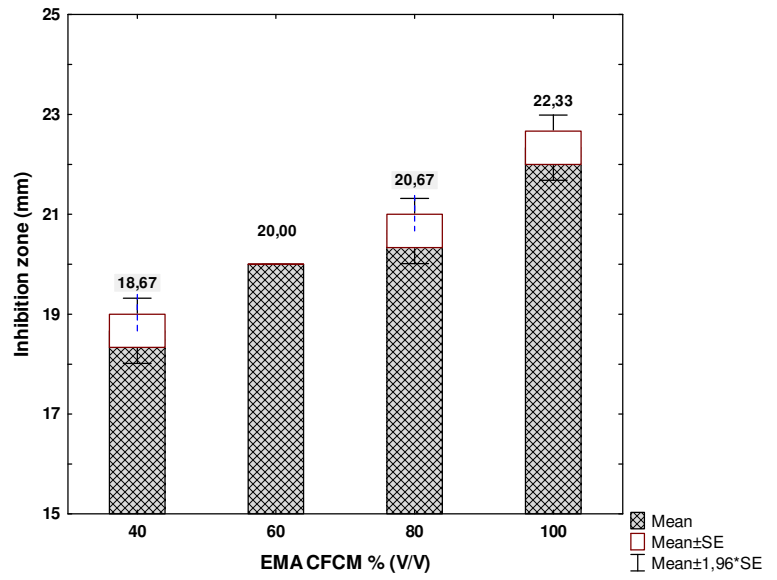

Fig. 1. Antibacterial activity of native cell-free conditioned media (CFCM) of Xenorhabdus budapestensis (EMA) against Erwinia amylovora $\mathrm{Ea} 1$ in agar diffusion test

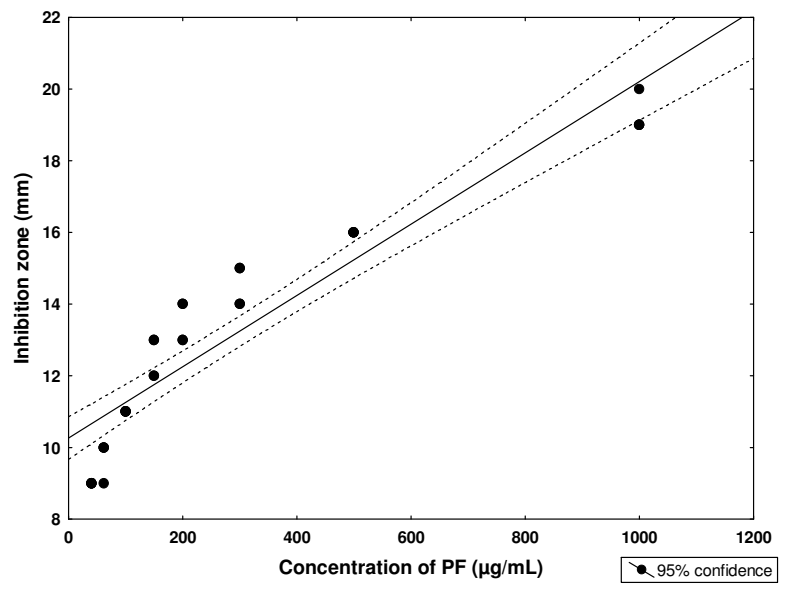

Fig. 2. Dose - effect study on the antibacterial activity of the peptide-rich fraction (PF) prepared from native cell-free conditioned media (CFCM) of Xenorhabdus budapestensis (EMA) on E. amylovora Eal in vitro

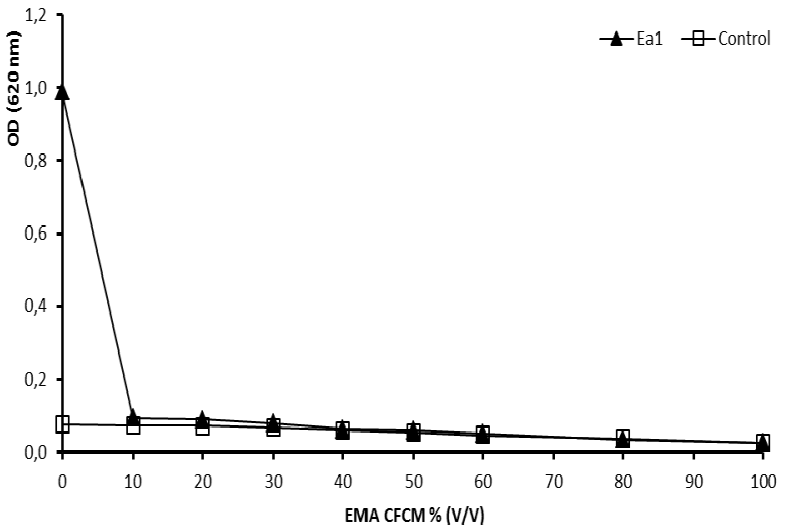

Fig. 3. Determination of the quantitative parameters of the bactericide (cytotoxic) activity of the native cell-free conditioned media (CFCM) of $X$. budapestensis (EMA) on Erwinia amylovora $\mathrm{Eal}(\mathbf{\Lambda})$ in liquid cultures. Control( $\square)$ :EMACFCM diluted with sterileLB mediaand without bacteria 


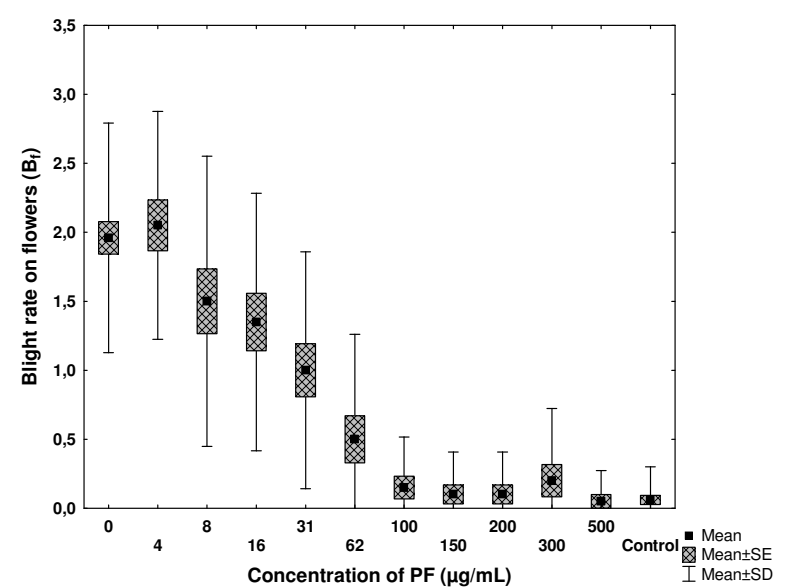

Fig. 4. Effect of preventive treatment with PF on the condition of dissected flowers subsequently infected with Erwinia amylovora Eal test bacterium. The blight rating $\left(\mathrm{B}_{\mathrm{f}}\right)$ was calculated based on the formula reported by Bertrand and Gottwald (1978): $\Sigma \mathrm{f}_{\mathrm{i}} \times \mathrm{n}_{\mathrm{i}} / \mathrm{n}$

found at a $95 \%$ significance level. The adjusted coefficient indicates an excellent fit $(\mathrm{r}=0.93)$.

Antimicrobial activity of the CFCM from EMA was measured in liquid media by the turbidimetric determination of bacterial growth following exposure to the test material in different concentrations for $24 \mathrm{~h}$. The cytotoxicity curve is presented in Fig. 3. The effect was dose dependent. The effective dose of CFCM (MID value) was found as $10 \%(\mathrm{~V} / \mathrm{V})$.

A MIC is generally regarded as the most basic laboratory measurement of the activity of an antimicrobial agent against an organism (Turnidge et al., 2003). Diluted samples of PF extracted from EMA CFCM were tested for antibacterial activity against $E$. amylovora $E a 1$ strain using standard methods. MIC and MBC were found as $8 \mu \mathrm{g} / \mathrm{mL}$ and $16 \mu \mathrm{g} / \mathrm{mL}$, respectively. It appeared that there was no considerable difference between the effective MIC and MBC values, thus the effect was bactericidal rather than bacteriostatic.

\section{Inplanta bioassay}

In preliminary experiments we demonstrated that undiluted cell-free culture filtrate of $X$. budapestensis is harmful to apple flowers. Treatment employing a hand-sprayer caused necrotic symptoms on blossoms. Therefore, further purified preparation of EMA was used for in vivo bioassay. Although the preparation has slightly lower efficiency against $E$. amylovora based on the results of agar diffusion test method, it would contain fewer compounds, which may damage apple flowers.

Data on effectiveness of the purified peptide-rich fraction (PF) on apple blossoms are presented in Table 1. The blight rating $\left(\mathrm{B}_{\mathrm{f}}\right)$ was calculated based on the formula reported by Bertrand and Gottwald (1978): $\Sigma \mathrm{f}_{\mathrm{i}} \times \mathrm{n}_{\mathrm{i}} / \mathrm{n}$, where $f_{i}$ indicated the individual infection rate of the flowers, $n_{i}$ is the frequency of each infection rate and $n$ is the number of flowers examined in the same way treatment. The development of fire blight symptoms on flowers with different treatments was compared based on a scale of 0 to 3 , so parametric tests cannot be used for the statistical analysis. Therefore, the overall comparison of the treatments was made by non-parametric Kruskal-Wallis test. The results on Fig. 4 show, that the preventive treatment of dissected flowers with $62 \mathrm{\mu g} / \mathrm{mL}$, or larger dose of PF significantly reduced the frequency of infection rate $\left(\mathrm{f}_{\mathrm{i}}\right)$ after the artificial infection with $E$. amylovora Eal compared to negative control (treated with sterile distilled water), and was significantly not different from the positive control (not infected with Eal). Treatment with 300 $\mu \mathrm{g} / \mathrm{mL}$ and higher dose caused necrotic symptoms on the petals of apple flower samples.

Data concerning average number of Eal cells were based on the results of colony forming units of Eal bacteria on LA media extracted from flowers and plated in replicate following incubation for $48 \mathrm{~h}$. Significant correlation was found between the doses of PF-treatment based on the number of isolated viable Eal cells from apple flower samples. However, the adjusted coefficient was fairly small $(\mathrm{r}=-0.56)$, indicating that this method has highly scattered. Nevertheless, the procedure is capable of demonstrating considerable differences in changes of number of viable Eal cells on flowers.

\section{Discussion}

Böszörményi et al. (2009) proved the efficacy of $X$. budapestensis cell-free culture filtrates in reduction of the fire blight symptoms in both laboratory and greenhouse experiments. This study was designed to control only vegetative shoot infection. CFCM from Xenorhabdus have never been investigated as a treatment for the blossoms of apple trees.

Primary blossoms are particularly important, because the fire blight lesions are initiated as the blossom infections and can directly

Table 1. Effectiveness of the purified peptide-rich fraction (PF) on apple blossoms

\begin{tabular}{|c|c|c|c|c|c|c|}
\hline \multirow{4}{*}{$\begin{array}{c}\text { Pre-treatment } \\
\text { Concentration } \\
\text { of EMA PF } \\
(\mu \mathrm{g} / \mathrm{mL})\end{array}$} & \multicolumn{6}{|c|}{ Evaluation } \\
\hline & \multicolumn{4}{|c|}{ Infection rate $\left(f_{i}\right)$} & \multirow{3}{*}{ Bf } & \multirow{3}{*}{$\begin{array}{l}\text { Average number of Eal cells } \\
\text { (CFU/flower) }\end{array}$} \\
\hline & $\mathbf{0}$ & 1 & 2 & 3 & & \\
\hline & \multicolumn{4}{|c|}{ Frequency of infection rate $\left(n_{i}\right)$} & & \\
\hline $\mathbf{0}$ & 4 & 6 & 28 & 12 & 1.96 & $1.0 \times 107$ \\
\hline 4 & 1 & 3 & 10 & 6 & 2.05 & $8.4 \times 106$ \\
\hline 8 & 3 & 9 & 3 & 5 & 1.50 & $6.2 \times 106$ \\
\hline 16 & 3 & 10 & 4 & 3 & 1.35 & $5.4 \times 106$ \\
\hline 31 & 6 & 9 & 4 & 1 & 1.00 & $2.8 \times 106$ \\
\hline 62 & 13 & 4 & 3 & 0 & 0.50 & $6.5 \times 105$ \\
\hline 100 & 17 & 3 & 0 & 0 & 0.15 & $1.1 \times 105$ \\
\hline 150 & 18 & 2 & 0 & 0 & 0.10 & $5.0 \times 104$ \\
\hline 200 & 18 & 2 & 0 & 0 & 0.10 & $6.3 \times 104$ \\
\hline 300 & 17 & 2 & 1 & 0 & 0.20 & $1.4 \times 105$ \\
\hline 500 & 19 & 1 & 0 & 0 & 0.05 & $3.8 \times 104$ \\
\hline Control & 47 & 3 & 0 & 0 & 0.06 & 0 \\
\hline
\end{tabular}


552

reduce yields, kill major limbs spreading toward, and supply inoculum for shoot infection and secondary blossom infection (Beer and Opgenorth, 1976). Furthermore, crop spraying against plant pathogenic bacteria is usually carried out during the bloom period of fruit-trees. Thus, spraying materials designed to prevent the infection must be able to protect from plant pathogens without damage of blossoms.

According to the evaluation of the in planta bioassay on artificially infected apple blossoms, purified preparation from EMA can provide a protective effect against the development of fire blight. Small populations of E. amylovora $\left(<10^{5} \mathrm{CFU}\right)$ associated with a treated flower are unlikely to be sufficient to induce symptoms. Preventive treatment with PF can significantly reduce the number of viable $E$. amylovora cells based on the data from the in vivo bioassay and the results of isolation of the bacteria from extracts of flowers.

The peptide-rich fraction prepared from $X$. budapestensis culture containing the antimicrobial compounds is a promising biological preparation suitable to reduce the fire blight symptoms when applied under controlled conditions prior to infection on apple blossoms.

\section{Conclusions}

For summary, it is confirmed that the secondary metabolites from the species $X$. budapestensis has a potential to control fire blight disease under controlled conditions. These studies represent a good basis for the performance of reliable field tests. Furthermore, entomopathogenic bacterium $X$. budapestensis produce compounds with a wide range of bioactivities and can provide novel active ingredients to improve new, effective agrobiologicals for plant protection.

\section{Acknowledgements}

This work was supported by the Ph.D. Program of the University of Pannonia and by the Fulbright Research Grant, grant number 1214102.

\section{References}

Akhurst RJ (1982). Antibiotic activity of Xenorhabdus spp., bacteria symbiotically associated with insect pathogenic nematodes of the families Heterorhabditidae and Steinernematidae. Journal of General Microbiology 128:3061-3065.

Ausubel FM, Brent R, Kingston RE, Moore DD, Seidman JG, Smith JA, Struhl K (1999). Short Protocols in Molecular Biology, 4th Edition. A compendium of methods from current protocols in molecular biology. John Wiley \& Sons, New York, USA.

Beer SV, Opgenorth DC (1976). Erwinia amylovora on fire blight canker surfaces and blossoms in relation to disease occurrence. Phytopathology 66:317-322.

Bertrand PF, Gottwald TR (1978). Evaluating fungicides for pear disease control. In: Zehr EI (Ed). Methods for evaluating plant fungicides, nematicides and bactericides. St Paul, Minnesota USA pp 179-181.

Boemare NE, Akhurst RJ, Mourant RG (1993). DNA relatedness between Xenorhabdus spp. (Enterobacteriaceae), symbiotic bacteria of entomopathogenic nematodes, and a Proposal to transfer Xenorhabdus luminescens to a new genus, Photorhabdus gen. nov. International Journal of Systematic Bacteriology 43:249-255.

Bonn WG, van der Zwet T (2000). Distribution and economic importance of fire blight. In: Vanneste JL (Ed). Fire Blight, the Disease and Its Causative Agent Erwinia amylovora. CAB International, Wallingford, UKpp 37-53.

Böszörményi E, Érsek T, Fodor A, Fodor AM, Földes LSz, Hevesi M, Hogan JS, Katona Z, Klein MG, Kormány A, Pekár S, Szentirmai A, Sztaricskai F, Taylor RAJ (2009). Isolation and activity of Xenorhabdus antimicrobial compounds against the plant pathogens Erwinia amylovora and Phytophthora nicotianae. Journal of Applied Microbiology 107:746-759.

CLSI (2012). Methods for Dilution Antimicrobial Susceptibility Tests for Bacteria That Grow Aerobically; Approved Standard - Ninth Edition. CLSI document M07-A9. Clinical and Laboratory Standards Institute, Wayne, PA.

Dutky SR, Thompson JV, Cantwell GE (1964). A technique for the mass propagation of the DD-136 nematode. Journal of Insect Pathology $6: 417-422$

Dzotam JK, Touani FK, Kuete V (2015). Antibacterial activities of the methanol extracts of Canarium schweinfurthii and four other Cameroonian dietary plants against multi-drug resistant Gram-negative bacteria. Saudi Journal of Biological Sciences doi: 10.1016/j.sjbs.2015.06.006.

Fodor A, Varga I, Hevesi M, Máthé-Fodor A, Racsko J, Hogan JA (2012). Novel Anti-Microbial Peptides of Xenorhabdus Origin against Multidrug Resistant Plant Pathogens. In: Bobbarala V (Ed). Biochemistry, Genetics and Molecular Biology - A Search for Antibacterial Agents. InTech pp 147-196.

Fuchs SW, Sachs CC, Kegler C, Nollmann FI, Karas M, Bode HB (2012). Neutral loss fragmentation pattern based screening for arginine-rich natural products in Xenorhabdus and Photorhabdus. Analytical Chemistry 84(16):6948-6955.

Fuchs SW, Grundmann F, Kurz M, Kaiser M, Bode HB (2014). Fabclavines: Bioactive Peptide-Polyketide-Polyamino Hybrids from Xenorhabdus. Chembiochem 15:512-516.

Furgani G, Böszörményi E, Fodor A, Fodor AM, Forst S, Hogan J, Katona Z, Klein MG (2008). Xenorhabdus antibiotics: a comparative analysis and potential utility for controlling mastitis caused by bacteria. Journal of Applied Microbiology 104:745-758.

Hastings P, Rosenberg SM, Slack A (2004). Antibiotic-induced lateral transfer of antibiotic resistance. Trends in Microbiology 12:401-404.

Hevesi M (1996). Appearance of fire blight in Hungary. Plant Protection 32:225-228 (in Hungarian).

Leclerc MC, Boemare NE (1991). Plasmids and Phase Variation in Xenorhabdus spp. Applied and Environmental Microbiology 57:25982601.

Lengyel K, LangE, Fodor A, Szállás E, Schumann P, Stackebrandt E (2005). Description of four novel species of Xenorhabdus, family Enterobacteriaceae: Xenorbabdus budapestensis sp. Nov., Xenorhabdus eblersii sp. Nov., Xenorhabdus innexi sp. Nov, and Xenorhabdus szentirmaii sp. Nov.Systematic and Applied Microbiology 28:115-122. 
Malnoy M, Martens S, Norelli JL, Barny MA, Sundin GW, Smits TH, Duffy B (2012). Fire blight: applied genomic insights of the pathogen and host. Annual Review of Phytopathology 50:475-494.

McInerney BV, Gregson RP, Lacey M, Akhurst RJ, Lyons GR, Rhodes SH, Smith DRJ, Lutz ME, White AH (1991). Biologically active metabolites from Xenorhabdus spp. part 1. Dithiopyrrolone derivatives with antibiotics activity. Journal of Natural Products 54:774784.

McInerney BV, Taylor WC, Lacey MJ, Akhurst RJ, Gregson RP (1991). Biologically active metabolites from Xenorhabdus spp. part 2. Benzopyran-1-one derivatives with gastroprotective activity. Journal of Natural Products 54:785-795.

McManus PS, Jones AL (1994). Epidemiology and genetic analysis of streptomycin-resistant Erwinia amylovora from Michigan and evaluation of oxytetracycline for control. Phytopathology 84:627-633.

Norelli JL, Burr TJ, Lo Cicero AM, Gilbert MT, Katz BH (1991). Homologous streptomycin resistance gene present among diverse Gram-negative bacteria in New York State apple orchards. Applied and Environmental Microbiology 57:486-491.

Pusey PL (1999). Water relations and infection by Erwinia amylovora based on crab apple blossom model. Acta Horticulturae 489:521-524.

Smart GC (1995). Entomopathogenic nematodes for the biological control of insects.Journal of Nematology 27:529-553.

Smith-Palmer A, Stewart J, Fyfe L (1998). Antimicrobial properties of plant essential oils and essences against five important food-borne pathogens. Letters in Applied Microbiology 26:118-122.

Sobiczewski P, Chiou C-S, Jones AL (1991). Streptomycin-resistant epiphytic bacteria with homologous DNA for streptomycin resistance in Michigan apple orchards. Plant Disease 75:1110-1113.
Thomas GM, Poinar GO (1979). Xenorhabdus gen. nov, a genus of entornopathogenic, nematophilic bacteria of the family Enterobacteriaceae. International Journal of Systematic Bacteriology 29:352-360.

Tóth M, Ficzek G, Király I, Honty K, Hevesi M (2013). Evaluation of old Carpathian apple cultivars as genetic resources of resistance to fire blight (Erwinia amylovora). Trees27:597-605.

Turnidge JD, Ferraro MJ, Jorgensen JH (2003). Susceptibility Test Methods: General Considerations. In: Murray PR, Baron EJ, Jorgensen JH, Pfaller MA, Yolken RH (Eds). Manual of Clinical Microbiology. American Society ofClinical Microbiology, Washington, USA 1103 p.

van der Zwet T, Beer SV (1995). Fire blight - its nature, prevention and control. A practical guide to integrated disease management. USDA. Agriculture Information Bulletin 631:97.

Viljevac M, Dugalic K, Stolfa I, Dermic E, Cvjetkovic B, Sudar R, Kovacevic J, Cesar V, Lepedus H, Jurkovic Z (2009). Biochemical Basis of Apple Leaf Resistance to Erwinia amylovora Infection. Food Technology and Biotechnology 47(3):281-287.

Webster JM, Chen G, Hu K, Li J (2002). Bacterial metabolites. In: Entomopathogenic Nematology. CABI Publishing, USA pp 99-115.

Xiao Y, Meng F, Qiu D, Yang X(2012). Two novel antimicrobial peptides purified from the symbiotic bacteria Xenorhabdus budapestensis NMC10. Peptides 35:253-260. 